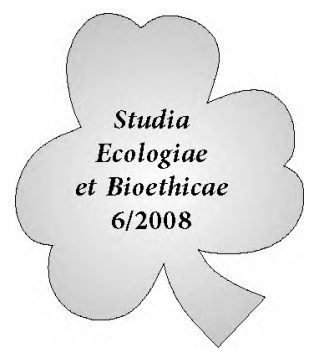

\title{
Etyczne podstawy polityki zrównoważonego rozwoju
}

\begin{abstract}
Wstęp
Hasło „rozwój zrównoważony” ostatnimi laty w Polsce zrobiło niesamowitą karierę, zaś w wielu krajach, w tym w państwach Unii Europejskiej wyznacza oficjalny trend właściwego prowadzenia polityki gospodarczej i społecznej, z uwzględnieniem imperatywu ochrony środowiska przyrodniczego. Wyznaje się tu bowiem zasadę, iż tylko odpowiedni, zrównoważony rozwój społeczno-gospodarczy kraju, który nie prowadzi do degradacji ekosystemów, jest w stanie zapewnić obywatelom wysoki poziom bezpieczeństwa przed destrukcją oraz zagwarantować należytą jakość ich życia.

Idea „rozwoju zrównoważonego” zakłada, iż obecnie żyjący ludzie są odpowiedzialni za stan środowiska oraz powinni pozostawić przyszłym pokoleniom godziwe warunki życia. Imperatyw poszanowania przyrody, działanie dla dobra przyszłych pokoleń, powoduje, iż wszelkie działania polityczne w tym zakresie, muszą być podbudowane na pewnych rozstrzygnięciach z zakresu etyki, zwłaszcza zaś jednej z jej subdyscyplin - etyki środowiskowej.

Ponadto trzeba również mieć na uwadze fakt, iż nawet najlepiej skonstruowane przepisy prawne i zręby polityki zrównoważonego rozwoju mogą okazać się nieskuteczne, w przypadku, gdy ogół obywateli nie będzie postrzegać przyrody jako wartości moralnej i społecznej. Zadanie to może zrealizować właśnie ekoetyka, która wypracowuje odpowiednio uzasadnione wartości i wsparte na nich normy ochrony przyrody, zaś za pomocą wychowania proekologicznego stara się je zaszczepić w świadomości społeczeństwa.

Zdaję sobie sprawę z faktu, iż tytuł mojej pracy jest bardzo szeroki, dlatego więc uznałem za stosowne zawęzić swoje refleksje do odpowiedzi na pytanie, jaki model na gruncie etyki środowiskowej - antropocentryczny czy biocentryczny, jest najbardziej optymalny dla uzasadnienia praktycznych, politycznych programów wdrażania zrównoważonego rozwoju. Rozróżnienie to jest istotne, ponieważ oba kierunki inaczej pojmują cel ochrony przyrody, antropocentryzm ma na względzie dobro człowieka, biocentryzm zaś dobro całej przyrody, której jednym $\mathrm{z}$ wielu elementów jest człowiek.
\end{abstract}


Zanim jednak to uczynię chciałbym najpierw scharakteryzować samą ideę zrównoważonego rozwoju.

\section{Ogólna charakterystyka idei „rozwoju zrównoważonego”}

Jak zauważył Grzegorz Zabłocki pojęcie „rozwój zrównoważony” jest polskim odpowiednikiem angielskiego terminu sustainable development, który na gruncie naszego, ojczystego języka jest trudny do przełożenia. Na ogół tłumaczy się go na różne sposoby, m.in. także jako „ekorozwój, rozwój trwały, rozwój samopodtrzymujący się, rozwój z poszanowaniem dóbr przyrody”'.

W kontekście historycznym wyrażenia tego użyła Barbara Ward, u schyłku lat sześćdziesiątych, w celu podkreślenia, iż należy zintegrować rozwój gospodarczy kraju, wraz z jednoczesnym zachowaniem równowagi przyrodniczej. Określenie to od tamtej pory zdobyło sobie dużą popularność, aczkolwiek fakt ten nie przyczynił się do jednolitego zdefiniowania tegoż pojęcia. Szczególnie istotna dla omawianej idei była treść raportu sporządzonego przez Światową Komisję ds. Srodowiska i Rozwoju z 1987 roku, w którym m.in. czytamy, iż rozwój zrównoważony to „zaspokajanie obecnych potrzeb bez naruszania możliwości zaspokajania potrzeb i aspiracji w przyszłości"’.

Za ważną datę w popularyzacji i postrzeganiu tej idei, należy również uznać rok 1992, w którym zorganizowano pod auspicjami ONZ w Rio de Janeiro konferencję pt. „Środowisko i Rozwój”, znanej jako „Szczyt Ziemi”. Przypomnę tylko, że w trzeciej zasadzie Deklaracji z Rio, wyartykułowano następujące zdanie: „Prawo do rozwoju musi być realizowane tak, ażeby sprawiedliwie połączyć rozwojowe i środowiskowe potrzeby obecnych i przyszłych generacji”." Đakże międzynarodowy, globalny program działań podbudowany ustaleniami tej konferencji, znany jako „Agenda 21”, upowszechnily w skali masowej ten nowy, współczesny model uprawiania polityki. ${ }^{4}$ Przeniknął on również do naszego kraju, gdzie „rozwój zrównoważony” stanowi normę konstytucyjną.

$\mathrm{Na}$ marginesie warto poczynić uwagę, iż oprócz zasygnalizowanych problemów definicyjnych brakuje także konkretnych recept, które umożliwiłyby realizację takiego pożądanego rozwoju w praktyce. ${ }^{5}$

1 G. ZABŁocKI, Rozwój zrównoważony: idee, efekty, kontrowersje (perspektywa socjologiczna), \oruń 2002, s. 7.

Cyt. $z a$ - ibidem.

3 Cyt. za - A. Papuziński, Wstęp, (w:) Zrównoważony rozwój: od utopii do praw człowieka, Bydgoszcz 2005, s. 9.

4 G. ZABŁoCKI, Rozwój zrównoważony, op. cit., s. 8.

5 Ibidem. 
G. Zabłocki zwrócil uwagę, iż w wielu polskich publikacjach utożsamia się „zrównoważony rozwój” z ekorozwojem, traktując te dwa terminy jako tożsame. Uczony ten uważa, iż interpretację tę należy uznać za błędną, ponieważ pojęcie ekorozwoju ogranicza się tylko do relacji między sferą gospodarczą a środowiskiem przyrodniczym, pomijając przy tym kwestię rozwoju społecznego, która obok dwóch wcześniej wymienionych komponentów stanowi integralną część procesu, nazywanego $\mathrm{w}$ międzynarodowych dokumentach i zagranicznej literaturze jako sustainable development. ${ }^{6}$

Biorąc pod uwagę to ważne rozróżnienie dokonane przez wyżej zacytowanego autora, w moim artykule przyjmuję, iż polityka zrównoważonego rozwoju integruje w swym obszarze właśnie te trzy sfery: gospodarczą (ekonomiczną), społeczną i ekologiczną (ochronę środowiska), które stara się odpowiednio zharmonizować w ramach optymalnego rozwoju.

Międzynarodowe dokumenty, jak i opracowania naukowe z tego zakresu, jednoznacznie wskazują, iż proces zrównoważonego rozwoju ma na celu zaspokojenie potrzeb współczesnych obywateli, ale również i przyszłych pokoleń, którym powinniśmy zagwarantować możliwość ich realizacji. W takim ujęciu zaznacza się więc troska i odpowiedzialność za dobro obecnych, jak i przyszłych generacji ludzi, co powoduje, iż inicjatywa zachowania zrównoważonego rozwoju musi zostać podbudowana na określonych podstawach etycznych. Uczynię to $\mathrm{w}$ dalszych partiach mojej publikacji.

\section{Antropocentryczne czy biocentryczne podstawy etyczne dla wdrażania polityki zrównoważonego rozwoju?}

Na początku chciałbym zauważyć, iż antropocentryzm i biocentryzm to dwa podstawowe ${ }^{7}$ i zarazem opozycyjne względem siebie modele uprawiania etyki środowiskowej. Warto je scharakteryzować, gdyż rozważania te mogą okazać się pomocne w dalszej części mojego tekstu. Chciałbym jednak zastrzec, iż prezentacja ta będzie miała charakter skrótowy, ponieważż ograniczone ramy tej pracy nie pozwalają na pełną i krytyczną analizę tych stanowisk, poprzestanę więc tylko na przedstawieniu ich głównych tez. ${ }^{8}$

6 Ibidem, s. 49.

7 Naturalnie modeli uprawiania etyki środowiskowej jest znacznie więcej, w literaturze z tego obszaru wymienia się oprócz antropocentryzmu i biocentryzmu także ekoetykę: egocentryczną, patocentryczną, holistyczną, a także etykę ochrony zwierząt. Autor tego artykułu do wymienionych dodaje także ekoetykę teocentryczną. Jednak w publikacji tej postanowilem skoncentrować się tylko na tych wybranych, które w mojej opinii najlepiej prezentują podstawowe ujęcia uprawiania tej dyscypliny.

8 Zainteresowanych Czytelników pragnących pogłębić swą wiedzę z tego zakresu, zachęcam do zapoznania się z następującymi publikacjami, z których również korzystałem przy opra- 


\subsection{Antropocentryczne i biocentryczne ujęcie etyki środowiskowej - refleksje natury ogólnej}

Nie zagłębiając się w szczegóły przypomnę tylko, iż etyka środowiskowa zakłada, że niszczenie przyrody jest moralnym złem, zaś jej przedmiot badań dotyczy zasad i norm ochrony, zniszczonego w dużym stopniu przez człowieka środowiska przyrodniczego. ${ }^{9}$ Ponadto ta współczesna gałąź etyki normatywnej, określa aktualne tendencje oraz możliwości dokonania zmian w dotychczasowych, tradycyjnych relacjach człowieka z przyrodą, która pozwoliłaby na utrzymanie równowagi naturalnej.

W miejscu tym zaznacza się doniosła rola pedagogiki środowiskowej - wspartej na fundamentach etycznych i aksjologicznych - która ukazywałaby przyrodę jako bezcenną wartość, starając się w procesie dydaktyczno-wychowawczym upowszechnić to założenie, ponieważ tylko wtedy zaistnieje realna możliwość, że społeczeństwo dostrzeże wagę ochrony przyrody ${ }^{10}$.

Jak już nadmieniłem w etyce środowiskowej spośród wielu nurtów można wyróżnić dwa podstawowe ujęcia: antropocentryzm i biocentryzm. Antropocentryczne ujęcie tej dyscypliny etycznej, zakłada, iż człowiek stanowi główny punkt odniesienia w rozwiązywaniu etycznych dylematów, dlatego też zobowiązania moralne mamy jedynie wobec ludzi. Przyrodę należy więc chronić tylko ze względu na dobro człowieka, które stanowi normę moralną tego kierunku. W ujęciu takim człowiek stanowi wartość autoteliczną, przyroda zaś wartość instrumentalną.

cowywaniu niniejszego podrozdziału pracy: J. PawŁowska, Sporne problemy etyki ekologicznej, „Kwartalnik Filozoficzny”, Kraków 1993, z.2, s.146-158; J. JARox́, Ekologia - Sozologia - Ekofilozofia - Ekoetyka - Ekonomia proekologiczna, Warszawa 1997; s.152-157; W. \Y ४ursKI, Główne kierunki i zasady etyki środowiskowej, (w:) Wprowadzenie do filozoficznych problemów ekologii. Pod red. A. Papuzińskiego, Bydgoszcz 1999, s.101-113; Z. PiąTeK, Etyka środowiskowa. Nowe spojrzenie na miejsce człowieka w przyrodzie, Kraków 1998; M.M. BonENBERG., Etyka środowiskowa. Zalożenia i kierunki, Kraków 1992; M. CiszeK, Etyka środowiskowa (ekologiczna) jako nowa dziedzina etyki na podstawie polskiej literatury przedmiotu, (w:) Filozofia polska $w$ okresie transformacji ustrojowej. Pod red. W. Słomskiego, Siedlce 2003, s.113-135; J.M. DoŁĘGA, Ekologia w teologii ifilozofii chrześcijańskiej, (w:) Wprowadzenie do filozoficznych problemów ekologii, op. cit., s. 133-162.

9 Por. W. BoŁoz, Bioetyka. Jej historia i sposoby ujmowania, „Studia Ecologiae et Bioethicae. Recensio Internationalis", nr 1, 2003, s.169; por. również: W. DYK, Bioetyka między jakościa iświętością życia, „Studia Ecologiae et Bioethicae. Recensio Internationalis”, nr 1, 2003, s.177-187; W. BoŁoz, Jaka bioetyka dla Europy i Polski na poczatku dwudziestego pierwszego wieku?, (w:) Życie i zdrowie czlowieka w tradycji i kulturze polskiej. Pod red. W. Boloza i E. WolniczPawłowskiej, Warszawa 2004, s. 129-150.

10 Zagadnienie to podjąłem w następującym artykule: M. Ciszer, Filozoficzne modele realizowania treści ekologicznych, (w:) Filozoficzne wizje i modele świata. Pod red. W. Kamińskiej is. Konstańczaka, Wyd. PAP, Słupsk 2002, s. 66-79. 
Adwersarze homocentryzmu, uważają, iż taki model myślenia przyczynił się do kryzysu ekologicznego, dlatego należy go odrzucić na rzecz modelu biocentrycznego. 区en nowy paradygmat etyczny przeciwstawia się tradycyjnej dominacji człowieka w przyrodzie, podkreślając, że homo sapiens nie stanowi jakiejś uprzywilejowanej pozycji w biosferze, ludzie zaś swoje kontakty powinni układać według scenariusza, w którym zasada dominacji gatunkowej powinna ustąpić regule równości i współdziałania. W tej wersji etyki środowiskowej człowiek nie stanowi więc wartości autotelicznej, ponieważ przysługuje ona całej ożywionej przyrodzie, zaś ludzki gatunek jest jedynie jednym z jej wielu elementów. Normą moralną jest więc tutaj dobro całej biosfery.

Zwolennicy etyki antropocentrycznej bronią się przed tak postawioną krytyką. Zwracają uwagę, iż w tym kierunku etycznym można wydzielić dwa stanowiska: skrajne i umiarkowane. Ujęcie skrajne uwzględnia tylko interesy gatunku ludzkiego, przyroda zaś pełni rolę przysłowiowego zbiornika surowców naturalnych, z którego człowiek może dowolnie czerpać. Natomiast w jej umiarkowanej wersji mamy do czynienia $\mathrm{z}$ postulatem zrównoważonego korzystania $\mathrm{z}$ bogactw natury, w taki sposób, aby nie naruszyć równowagi ekosystemu, gdyż miałoby to negatywny wpływ na egzystencję obecnych społeczeństw, jak i przyszłych pokoleń (mamy więc tu do czynienia z ideą zrównoważonego rozwoju).

Antropocentryzmu w wersji skrajnej nie da się utrzymać, chociażby z powodu, że globalna degradacja przyrody przyczynić się może do zagłady ludzkości, co stoi w jawnej sprzeczności z zasadami etycznymi uznającymi dobro człowieka za swój nadrzędny cel. W zasadzie dla takiego stanowiska używanie określenia „antropocentryzm” jest nadużyciem, ponieważ mamy tu do czynienia z egocentryczną wizją korzystania $z$ dóbr przyrody. Lokalizuje ona $w$ centrum swojego zainteresowania wyłącznie dobro własne, ewentualnie działających jednostek, czy różnych grup, broniących swych partykularnych interesów, nie uwzględniając przy tym prawa innych ludzi do czystego, nieskażonego środowiska. Prowadzi to ostatecznie do degradacji przyrody.

Zwolennicy antropocentryzmu, z kolei krytykują biocentryzm, za to, iż nie traktuje człowieka jako wartości nadrzędnej, redukując go do zwykłego elementu przyrody, jak inne jej ożywione twory. Stanowisko takie wydaje się im zbyt skrajne, które może w końcowym efekcie doprowadzić do nowej formy totalitaryzmu ekologicznego i tym samym naruszyć prawa człowieka. Broniąc swojego stanowiska zwracają też uwagę, iż etyka sama w sobie jest antropocentryczna, gdyż tylko ludzie mają możliwość odróżnienia dobra od zła (a przyroda takich wzorów nam nie daje), dlatego też tylko od nich wymaga się odpowiedzialności za czyny, również te wobec przyrody. Zresztą tak rozumiany homocentryzm nie musi być sprzeczny z ideą biocentryzmu czy ekocentryzmu, ponieważ to człowiek zniszczył wiele $z$ naturalnego bogactwa życia, ale $z$ drugiej strony tylko on może ten stan naprawić. 
Na marginesie abstrahując od głównego wątku rozważań, chciałbym zauważyć, iż literatura z zakresu ekofilozofii i ekoetyki w zasadzie przemilcza (ewentualnie tylko sygnalizuje) jeszcze jeden w mojej opinii bardzo ważny model uprawiania etyki ekologicznej, jakim jest paradygmat teocentryczny, który staram się od jakiegoś czasu wprowadzić do piśmiennictwa z tego obszaru. ${ }^{11}$ Wydaje mi się, iż teocentryzm unika skrajności i kontrowersji, jakie stały się udziałem stanowisk: antropocentrycznych i biocentrycznych, w filozofii środowiskowej, można więc go uznać za model optymalny i „zrównoważony”.

Chciałbym tu tylko nadmienić, iż teocentryczna wersja etyki środowiskowej nakazuje rozpatrywać wszelkie relacje między działaniami moralnymi człowieka a przyrodą, w odniesieniu do Boga, jako Stwórcy przyrody i kosmosu. Przyroda posiada wartość ze względu na Boga, który ją stworzył i utrzymuje nadal w istnieniu, należy więc środowisko naturalne traktować w kategoriach swoistego dobra. Człowiek jako istota wyjątkowa powinien pełnić rolę dobrego strażnika, gospodarza i opiekuna świata przyrody, którą otrzymał w darze od Stwórcy. Natomiast niszcząc przyrodę wskutek konsumpcyjnego stylu życia, sprzeciwiamy się Bogu, a więc grzeszymy i czynimy zło. Đen teocentryczny model ekoetyczny można uznać również za przysłowiową „trzecią drogę" pomiędzy antropocentryczną i biocentryczną wersją etyki środowiskowej. $Z$ jednej bowiem strony akcentuje wyjątkowość człowieka w świecie przyrody a jego godność za normę moralną, z drugiej zaś dopatruje się w przyrodzie wartości, ze względu na Boga, który ją stworzył i ofiarował człowiekowi, jako jej gospodarzowi.

Po tej charakterystyce warto zastanowić się, który z tych dwóch podstawowych kierunków w ekoetyce powinien stanowić punkt odniesienia dla politycznych inicjatyw wprowadzania rozwoju zrównoważonego.

\subsection{Antropocentryczny i biocentryczny paradygmat uzasadnienia idei zrównoważonego rozwoju}

Jak wcześniej nadmieniłem skrajny antropocentryzm, który wolę jednak określać bardziej precyzyjnie mianem etyki egocentrycznej, nie może stanowić

11 Por. np.: M. Ciszek, Antropocentryczne czy teocentryczne podstawy chrześctjańskiej etyki środowiskowej, (w:) Etyka środowiskowa wyzwaniem XXI wieku. Pod red. J.W. Czartoszewskiego, Warszawa 2002; M. CIszek, Antropoprioryczna koncepcja chrześcijańskiej etyki środowiskowej oraz jej implikacje w bezpieczeństwie ekologicznym, (w:) Ekofilozofia, bioetyka, etyka biznesu. Aktualne problemy wspótczesności. Pod red. J. Jaronia, Siedlce 2004; M. CiszEK, Ekologiczne aspekty katolickiej teologii moralnej, „Studia Ecologiae et Bioethicae”. Recensio Internationalis, nr 2, 2004; M. CISzeK, Zasada poszanowania przyrody. Teocentryczny aspekt katolickiej etyki środowiskowej, (w:) Rozmaitości ekofilozofii. Pod red. A. Skowrońskiego, Olecko 2006; M. Ciszek, Teocentryczny model etyki środowiskowej, „Studia Ecologiae et Bioethicae”. Recensio Internationalis, nr 4, 2006; M. CISzEK, Rola etyki środowiskowej w edukacji ekologicznej oraz jej implikacje w katechezie, „Studia Ecologiae et Bioethicae”. Recensio Internationalis, nr 4, 2006. 
właściwego modelu etycznego, który sprzyjałby realizacji zrównoważonego rozwoju, ponieważ stanowi on jego zaprzeczenie. Na gruncie ochrony środowiska taki model prowadzi jedynie do globalnej degradacji przyrody, ponieważ jest wynikiem krótkowzrocznej polityki ekologicznej zasadzającej się na egoistycznej moralności. W krajach zachodnich (np. w Niemczech) znane są przypadki, iż chroni się własny region, $w$ ten sposób, że skierowuje się zanieczyszczenia atmosferyczne czy odpady radioaktywne na obce tereny, co niektórzy uczeni nazywają agresją ekologiczną. W wielu innych państwach chroni się również własny kraj skierowując zanieczyszczenia poza granice swojego terytorium. ${ }^{12}$

Naturalnie taką politykę należy uznać nie tylko za niemoralną, ale również za mało pragmatyczną, i nieefektywną w dłuższej perspektywie. Zapomina się tutaj o tym, iż cała nasza planeta, stanowi wzajemnie powiązany ze sobą ekosystem i zakłócenie jego równowagi, w którymś z elementów znajdujących się nawet w odległych rejonach geograficznych, spowoduje olbrzymie szkody, negatywnie wpływające na stan zdrowia (a być może nawet na życie) mieszkańców kraju uprawiającego tak niebezpieczną politykę sozologiczną.

W piśmiennictwie z zakresu ekofilozofii toczą się dyskusje o to, na jakim modelu etycznym - $t \mathbf{j}$. antropocentrycznym czy biocentrycznym, należy budować szczególowe polityczne programy wdrażania zasad zrównoważonego rozwoju. W zasadzie chodzi tu o odpowiedź na pytanie czy idea zrównoważonego rozwoju powinna mieć na względzie dobro człowieka (ujęcie antropocentryczne) czy dobro całej przyrody (model biocentryczny, holistyczny). Przedstawię tutaj argumenty przemawiające na korzyść jednego i drugiego stanowiska, uwzględniając także głosy krytyczne.

Na wstępie chciałbym nawiązać do wspomnianej i historycznej już II konferencji w Rio de Janeiro z 1992 roku, w której starano się zbudować podwaliny pod nową erę w rozwoju ludzkości, tzw. Erę ekologiczną, mającą zastąpić dotychczasową Erę przemysłową, nadmiernie eksploatującą środowisko naturalne w służbie rozwoju gospodarczego, wprowadzając na jej miejsce zrównoważony rozwój. Ma ona na celu zastąpić kapitalistyczną ekonomię zysku nową ekonomią proekologiczną, pozwalającą w odpowiedni sposób zarządzać zasobami przyrodniczymi naszej planety ${ }^{13}$. Pierwsza $z$ dwudziestu siedmiu zasad Deklaracji z Rio, zwanej powszechnie Kartą Ziemi podkreśla, iż „Istoty ludzkie stanowią centrum zainteresowania w procesie zrównoważonego rozwoju. Mają prawo do zdrowego oraz twórczego życia w harmonii z przyrodą"14. Nietrudno pokusić się o refleksję, iż przytoczony cytat świadczy na korzyść antropocentrycznej interpretacji roz-

12 Por. J. Jaroń, Ekologia - Sozologia..., op. cit., s. 153.

13 E. PуєкA-Gutowska, Ekologia z ochrona środowiska, Warszawa 2000, s. 244.

14 Z. PIĄTEK, Czlowiek jako podmiot zrównoważonego rozwoju: konsekwencje filozoficzno-społeczne, (w:) Zrównoważony rozwój: od utopii do praw czlowieka, op. cit., s. 15. 
woju zrównoważonego. 区akie podejście jest również charakterystyczne m.in. dla polskiego znawcy tego przedmiotu Stefana Kozłowskiego. ${ }^{15}$

G. Zabłocki zauważa, iż spośród wielu określeń rozwoju zrównoważonego, jakie były popularne w latach dziewięćdziesiątych, na uwagę zasługuje jedna z nich, często traktowana jako jego definicja, która brzmi następująco „Stabilny rozwój oznacza rozwój, który zaspokaja potrzeby obecne, nie pozbawiając przyszłych pokoleń możliwości zaspokojenia ich potrzeb"16. W takim ujęciu wzywa się do takiego przeorientowania dotychczasowej polityki gospodarczej, nastawionej na szybki sukces okupiony często nieodwracalnymi stratami w środowisku naturalnym na rzecz efektów może nie błyskawicznych, ale za to o wiele bardziej korzystnych, z których cieszyć się będą w przyszłości następne pokolenia. Pojawia się tutaj postulat „solidarności międzypokoleniowej”, który polega na urzeczywistnieniu przyszłym generacjom takich warunków bytu, które nie będą gorsze od aktualnych. Autor ten zwraca uwagę, iż zrównoważony rozwój jest pojęciem znacznie szerszym, niż ekorozwój, ponieważ bierze pod uwagę również postulat zapewnienia odpowiedniego rozwoju społecznego (ludzkiego dobrobytu i odpowiednich warunków jego życia), stawia więc interes człowieka w centrum swego zainteresowania. „Ustanawiany jest zatem antropocentryczny charakter rozwoju zrównoważonego (czego brak w niektórych koncepcjach ekorozwoju), jednak inny (mniej partykularny) niż ten, który znajduje się w uzasadnieniach wzrostu PKB, przedstawianych we współczesnych społeczeństwach". ${ }^{17}$

$Z$ tego typu antropocentryczną wykładnią idei zrównoważonego rozwoju polemizuje Zdzisława Piątek. Uczona jest zdania, iż wyrażone w pierwszym punkcie Deklaracji z Rio stwierdzenie, że istoty ludzkie stanowią centrum zainteresowania procesu zrównoważonego rozwoju i mają prawo do zdrowego i twórczego życia w harmonii z przyrodą, nie posiada wydźwięku antropocentrycznego - jak się na pozór wydaje - podkreślono tu bowiem jedynie fakt, iż człowiek, w przeciwieństwie do zwierząt, które w sposób czysto biologiczny i niezależny od nich dostosowują się optymalnie do środowiska „musi świadomie uruchomić mechanizmy zrównoważonego rozwoju"18. Ponadto zauważa, że człowiek, "podobnie jak inne istoty żywe, ma prawo do zdrowego i twórczego życia, ale także i ten postulat nie ma charakteru antropocentrycznego, gdyż jego autentyczna realizacja przy zachowaniu harmonii z przyrodą może się dokonać tylko w sposób nieantropocentryczny. Zdrowe życie człowieka jest możliwe tylko w połączeniu z troską o zdrowie biosfery"19. Może się to stać tylko, wtedy, gdy ludzie zrezygnu-

15 Por. St. KozŁowski, Zrównoważony rozwój w pięć lat po Rio de Janeiro, „Człowiek i Przyroda”, nr 8-9, 1998.

16 Cyt. za - G. ZaBŁocki, Rozwój zrównoważony, op. cit., s. 40.

17 Ibidem.

18 Z. PiąTeK, Czlowiek jako podmiot zrównoważonego rozwoju, op. cit., s. 23.

19 Ibidem. 
ją z konsumpcyjnego modelu życia oraz przyjmą i zinternalizują nową hierarchię wartości o charakterze biocentrycznym.

Naturalnie zwolennicy etyki antropocentrycznej argumentują, że na jej gruncie istnieje także możliwość racjonalnego i przekonującego uzasadnienia ochrony przyrody, ukazując ją jako wartość instrumentalną, która prowadzi do zachowania ludzkiego życia i zdrowia stanowiącego wartość nadrzędną (autoteliczną). Dobro człowieka uzależnione jest tu od dobrego stanu przyrody, z tego też powodu należy zachowywać zasady zrównoważonego rozwoju. Odpowiedzialność za przyrodę wynika więc z odpowiedzialności wobec czlowieka, dlatego obwinianie etyki antropocentrycznej za destrukcję przyrody jest nieporozumieniem, gdyż w jej interesie leży wręcz zachowanie odpowiedniej równowagi w ekosystemach, poprzez umiarkowane korzystanie z dóbr przyrody, po to, aby pozostawić je w spadku przyszłym pokoleniom. Za kryzys ekologiczny obwiniają oni ludzki egoizm, nie uwzględniający dobra innych ludzi.

Aby nie zostać posądzonym o stronniczość, chciałbym tutaj zauważyć, iż nie sposób przyznać racji humanistom krytykującym tę umiarkowaną wersję antropocentryzmu na gruncie ekologii, za to, że nie jest ona skuteczna, ponieważ, jak zauważa Dariusz Kiełczewski „większość ludzi w istocie rzeczy nie przejmuje się powyższymi nakazami, uznając za słuszne to, co jest wygodne - odbierając szczególne miejsce ludzi w świecie jako uprawnienie do arbitralnej i nieograniczonej ingerencji w świat przyrody"20. Dendencja taka prowadzi ludzkość nieuchronnie do widma ekologicznej katastrofy.

Pomimo tej obawy wydaje mi się, iż konsekwentne odrzucenie antropocentryzmu i przyjęcie biocentrycznej hierarchii wartości oraz naturalistycznej wizji człowieka $^{21}$ - według których stanowi on zaledwie jeden $\mathrm{z}$ pośród wielu innych zwierzęcych gatunków - może sprowadzić ludzkość na moralne manowce i doprowadzić do radykalnych rozwiązań zgubnych dla ludzkości. Można się tego spodziewać po wypowiedziach niektórych skrajnych członków ruchu Earth First! popierających zagładę wielu istnień ludzkich dla dobra przyrody. Biocentryzm należałoby więc uznać za nurt zbyt skrajny - daleki od zrównoważonego rozwoju.

${ }^{20}$ D. KIEŁczewski, Aksjologiczne aspekty polityki ekologicznej, (w:) Polityka ekologiczna III Rzeczpospolitej. Pod red. A. Papuzińskiego, Bydgoszcz 2000, s. 422.

21 Cytowana profesor Z. Piątek uważa, iż „lepsze ramy światopoglądowe do realizacji zrównoważonego rozwoju stwarza naturalizm, gdyż uznając, że człowiek jest zaledwie jednym z gatunków uczestniczących w ziemskiej epopei życia, nie jest obciążony przekonaniem, iż gatunek ludzki stworzony na obraz i podobieństwo Boga jest ponad przyrodą i dlatego nie obowiązują go przyrodnicze ograniczenia." (Z. PIĄTEK, Człowiek jako podmiot zrównoważonego rozwoju, op. cit., s. 26). Waka teza Autorki w pewnej mierze jest słuszna, aczkolwiek nie wydaje mi się do końca przekonywująca, w zasadzie możliwa byłaby również na gruncie naturalizmu interpretacja, że człowiek jest gatunkiem drapieżnym, i jak przystało na drapieżnika przekształca przyrodę oraz zabija dla własnej korzyści (walka o byt!) inne słabsze gatunki, nie potrafiące się przed nim obronić. 
Być może takie wypowiedzi są dalekie od dobrych intencji przedstawicieli nurtów nawiązujących do biocentryzmu, lecz świadczy to tylko, o tym, iż w praktyce, na płaszczyźnie politycznej zrealizowanie idei biocentrycznych jest niemożliwe, bez uprzedniego przyjęcia w niejawny sposób norm uwzględniających w centralnym miejscu interes człowieka. W przeciwnym wypadku, jak zauważa cytowany D. Kiełczewski może grozić nam etyczna próżnia, którą „dostrzegają i obawiają się jej również niektórzy autorzy biocentryczni”22. Powołuje się tutaj na wypowiedź twórcy ekologii głębokiej Arne Naess'a ${ }^{23}$, który zwraca uwagę, iż jego „kierunek zawiera w sobie szczególne zobowiązania wobec ludzi. Obowiązkiem ojca jest zapewnienie pożywienia synowi. Gdyby zaistniała taka sytuacja, że mógłby to zrobić jedynie zabijając ostatniego tygrysa, ostatniego przedstawiciela gatunku, to też musiałby to zrobić (...) \o, co ja natomiast głoszę, to żeby było lepiej dla samych ludzi, gdyby było ich na ziemi mniej". ${ }^{24}$

Na podstawie powyższego cytatu można więc przyjąć, iż polityka państwa, która stara się zrealizować idee zrównoważonego rozwoju, jeśli ma być realistyczna musi uwzględniać dobro swoich obywateli, z samej więc definicji jest już antropocentryczna.

$\mathrm{Na}$ zakończenie tej części paragrafu pragnę jeszcze raz przypomnieć, iż stanowiskiem na gruncie ekofilozofii, które jest w stanie przezwyciężyć problemy i kontrowersje jakie stały się udziałem opozycyjnych: antropocentrycznych i biocentrycznych stanowisk, może być teocentryzm, ponieważ podkreśla wyjątkowość człowieka w przyrodzie, jednocześnie zaś dopatruje się w bytach przyrodniczych wartości, ze względu na Boga, który ją stworzył i przekazał w darze człowiekowi, jako jej zarządcy. ${ }^{25}$

\section{Zakończenie}

Kontrowersje na linii: antropocentryzm umiarkowany - biocentryzm nadal dzielą wielu ekofilozofów. Uważam jednak, iż na gruncie zrównoważonego rozwoju należy zwrócić uwagę na rzeczy, które stanowiska te łączą. 『o co wspólne dla tych kierunków to fakt, iż należy chronić przyrodę oraz troska o dobro człowieka, co prawda $\mathrm{w}$ antropocentryzmie stawiana jest ona na pierwszym planie, zaś w biocentryzmie tylko w kontekście troski o dobro całej przyrody, której częścią jest także człowiek. Oba kierunki również zgadzają się z tezą, że za zły stan przyrody odpowiada człowiek, ale również przyjmują, iż tylko on, ten niekorzystny stan może naprawić.

\footnotetext{
D. KIEŁcZEWsKI, Aksjologiczne aspekty polityki ekologicznej, op. cit., s.423.

Zob. A. NaEss, Rozmowy, Bielsko-Biała 1992.

Cyt. za - D. KieŁczewski, Aksjologiczne aspekty polityki ekologicznej, op. cit., s.423-424.

${ }_{25}$ Zaznacza się tu ogromna rola Kościoła, zwłaszcza księży i katechetów w propagowaniu ekologicznego przesłania, w kontekście teocentrycznej skali wartości. Ich działalność ukazująca niszczenie przyrody jako swoisty "grzech ekologiczny”, mogłaby przyczynić się do pozytywnego przeorientowania dotychczasowych postaw wobec przyrody wiernych.
} 


\title{
The ethical bases of policy of sustainable development
}

\begin{abstract}
SUMMARY
The idea of sustainable development set up that at presently living people are responsible for condition of environment and they should leave future generation decent circumstances of life. This imperative of respecting of nature, activity for goods of future generation causes that every politicial operation in this range must be underpinned on certain deciding from range of ethic especially on one of it's subdiscipline-environmental ethic. Unfortunately, this ethical discipline is not a monolith, because it is possible to find it's other streams witch tries to answer a question: why should we protect the nature? Especially two opposition streamas deserve notice anthropocentic and biocentric position, witch differently comprehend purpose and bases of protection of nature. The anthropocentism has on respect goods of the person but biocentrism goods of whole nature, witch one of the many elements is a man. In this publication I try to establish, witch from this two ethical models is most optimal for practical, political programs of accustoming of sustainable development.
\end{abstract}

